2011

\title{
The American "Rule": Assuring the Lion His Share
}

James Maxeiner

University of Baltimore School of Law, jmaxeiner@ubalt.edu

Follow this and additional works at: http://scholarworks.law.ubalt.edu/all_fac

Part of the Civil Procedure Commons, Courts Commons, and the Legal Profession Commons

\section{Recommended Citation}

The American "Rule": Assuring the Lion His Share, in Cost and Fee Allocation in Civil Procedure: A Comparative Study (M.

Reimann, ed., Ius Gentium: Comparative Perspectives on Law and Justice 11, 2011)

This Book Chapter is brought to you for free and open access by the Faculty Scholarship at ScholarWorks@University of Baltimore School of Law. It has been accepted for inclusion in All Faculty Scholarship by an authorized administrator of ScholarWorks@University of Baltimore School of Law. For more information, please contact snolan@ubalt.edu. 


\title{
Chapter 26 \\ The American "Rule": Assuring the Lion His Share
}

\author{
James R. Maxeiner
}

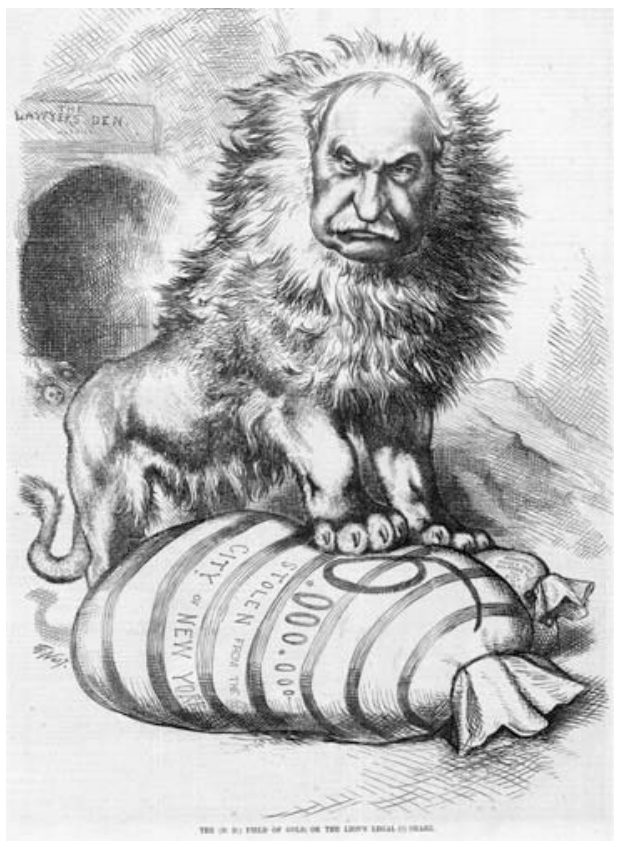

The (D. D.) Field of Gold, or The Lion's Legal (?) Share

Thomas Nast, HARPER'S WeEKLY MAGAZINE, January $15,1876^{1}$

(C) 2011, James R. Maxeiner, J.D., Cornell; LL.M., Georgetown; Ph.D. in Law, Ludwig Maximilian University (Munich, Germany). Associate Professor of Law and Associate Director, Center for International and Comparative Law, University of Baltimore School of Law.

${ }^{1}$ The lawyer is the great reformer, David Dudley Field, Jr. The cave in the background is marked "The Lawyers' Den." All three of the illustrations in this article are of Field.

J.R. Maxeiner $(\bowtie)$

Center for International and Comparative Law, University of Baltimore School of Law, Baltimore, MD, USA

e-mail: jmaxeiner@ubalt.edu 


\subsection{Rules, Practices and Reasons}

\subsubsection{Main Features}

The system of attorneys' fees in the United States has two characteristic features: (1) no fee-shifting (the "American rule"); and (2) fees set by agreement between lawyers and clients unrestricted by law ("unregulated fee agreements").

American practice of no indemnity. The practice in America is that each party pays his own lawyer her fee. Consequently losers do not make winners whole through paying their attorneys' fees. Winners recover less than their full claims after they pay their lawyers. Although called the "American Rule," it is better named the American practice, since rarely is it compelled by statute or precedent. It does not apply to court costs, which even in America, by rule are shifted to losers.

Unregulated fee agreements. Attorneys' fees are set by agreement of lawyers and their clients. They are usually unregulated by fee schedules or judicial determinations. Most common in the United States are hourly fees, contingent fees in litigation, and flat charges for specific services. Lawyers and their clients are free, however, to structure their fees using a combination of these three elements in just about any way they wish.

\subsubsection{American Exceptionalism}

According to the General Report, the American practice of "open rejection of the loser pays principle and the actual refusal to shift the lion's share of litigation expenses in the vast majority of cases sets the United States apart from the rest of the systems covered here." [1.2.1.3] That the "vast majority of systems embrace the loser-pays principle ... reflects primarily an idea of basic fairness ...: it seems just that the loser must compensate the winner." [1.2.3.1] In the asserted justification for fee rules, the General Report advises, the United States stands apart: it is "the only country predicating its basic cost rule purely on instrumentalist grounds." $[1.2 .3 .3]^{2}$ When it comes to fee agreements, according to the General Report, the United

\footnotetext{
They were drawn not to lambaste his work as a law reformer, but for his work for political and business interests. He represented "Boss" Tweed of Tammany Hall, and Fisk and Gould in the Erie railroad scandal. See Philip J. Bergan, David Dudley Field: A Lawyer's Life, in The Fields and the Law 21, 37-47 (1986). When Field died, Harper's Weekly noted his death by reprinting on the entire front page the painting of him by Robert Gordon Hardie in the Hall of the Court of Appeals in Albany. 38 HARPER's WeEkLY 361 (April 21, 1894).

2 The General Report observes that fairness arguments can be made in defense of American no-indemnity practice and singles out for mention the unpredictability of legal
} 
States is not alone. Other systems allow lawyers and clients to agree on fees that are over and above fees shifted. Binding fee schedules are "on the decline." [1.3.2.2] The General Report speaks of "yet another "Americanization' of law in many parts of the world." [1.3.2.2] The General Report observes three costs in freeing fees from regulation: it is incompatible with full fee shifting; it creates predictability and fairness issues; and it invites second-stage litigation about what is a reasonable fee. [1.3.2.2]

According to the United States National Report, at one time, many American states, including New York, were within today's worldwide norms. Fee shifting and fee schedules were parts of the American legal landscape. ${ }^{3}$ According to David Dudley Field, Jr., the great reformer and lawyer satirized in the three illustrations in this article, in 1842 it was a proposition "which scarce anyone will object to ... that the losing party ought to indemnify the other so far as he can against his losses by the suit." 4 Only in the second half of the nineteenth century did no indemnity become the national norm and fee regulation and shifting disappeared.

The General Reporter invites the National Reporter to explain why the United States rejects loser pays and the simple justice that stands behind it. I accept the invitation. My explanation is subjective and tentative.

decisions. [1.2.3.3, Note 71] That argument rejects an underlying assumption of feeshifting, that law is workably certain. That the argument has traction in the United States is attributable to the uncertainty of American law. In this conception, legal process is more of a method for divining an authoritative decision than an application of law to facts. On certainty and uncertainty, see James R. Maxeiner, Legal Certainty and Legal Methods: A European Alternative to American Legal Indeterminacy?, 15 Tulane J. INT'L \& COMP. L. 541 (2007); James R. Maxeiner, Legal Indeterminacy Made in America: American Legal Methods and the Rule of Law, 41 VAlParaiso U.L. Rev. 517 (2006).

${ }^{3}$ James R. Maxeiner, Cost and Fee Allocation in Civil Procedure, 58 AM. J. ComP. L. Supp. 195, 216-219 (2010). See John Leubsdorf, Toward a History of the American Rule on Attorney Fee Recovery, 47 Law \& Contemp. Problems 9 (1984). Professor Leubsdorf's article remains the most insightful examination of fee and cost-shifting in the United States. Specifically on the presence of fee schedules in early America, see 1 anton-Hermann Choust, The Rise of the Legal Profession in America 85-89, 129-132, 159-160, 317-319 (1965). On the decline and oceasional revival see WiLLIAM G. Ross, The Honest Hour: The Ethics of Time-Based Billing by Attorneys 9-17 (1996).

${ }^{4}$ David Dudley Field, Letter, printed as Appendix To the report of the Committee on the Judiciary, in relation to the more simple and speedy administration of justice, State of NeW-York, RePort in PART Of THE COMmitTeE ON THE JUdiciary, IN RELATion to the administration of justige, Document No. 81 (1842), at 55 collected in 5 Doguments of the Assembly of the State of New-York Sixty-fourth [sic, 65 ${ }^{\mathrm{TH}}$ ] SESSION (1842). [Bibliographic notes: the Appendix was sometimes distributed separately from the whole committee report. The committee report is collected in the documents series, in which each document is separately paginated. This volume is as of this writing available as a Google book.] 


\subsubsection{Lawyers Drive Civil Justice}

The machinery by which justice is wrought out has always been, and must forever remain, the creation of the profession.... No one thinks of challenging the right of the bar to determine the methods of which the remedies affecting the profoundest concerns of life shall be administered.

Charles M. Wilds Address Before the Vermont State Bar Association (1894) ${ }^{5}$

That private lawyers are the driving force behind civil justice explains the existence of the American practices of no indemnity for attorneys' fees and unregulated fee agreements. That lawyers are self-regulating explains why these practices continue. That lawyers control the conduct of litigation explains the great effect these practices have in the United States.

Self-regulating. Lawyers in the United States regulate themselves. With respect to fees they are little constrained by supervisory laws or authorities, even by those of their own making. ${ }^{6}$ Moreover, there are no government bodies that have responsibility for the overall state of civil justice. ${ }^{7}$

Lawyers control litigation. Lawyers in the United States control the course of civil litigation. Judges are by and large passive observers. Lawyers, and not judges, define issues in disputed cases. They decide what evidence to take. They call witnesses and question them. Lawyers even write the first drafts of instructions that judges give to juries and of findings of fact and conclusions of law that judges use to decide cases without juries. ${ }^{8}$

The American "rule" was never legislated; it grew up as a practice. There is no rule; there is an absence of rules. In the absence of rules, practices are unguided by binding direction. It is not completely accurate to say that

\footnotetext{
5 An Address on Common law Pleadings, Before the Vermont Bar Association, OCTOBER 9, 1894 (1894).

${ }^{6}$ See Lester Brickman, Lawyer Barons: What Their Contingency Fees Really Cost AMERICA 468-469 (2011) ("no profession is as exempt from societal control as is the legal profession. ... Lawyers' self-regulatory power largely flows from the judiciary's seizure of control over the practice of law ... to deprive legislatures of their historic authority to regulate lawyers....").

7 The United States Department of Justice and the offices of the attorneys general of the several states do not have responsibilities comparable to German and other similar ministries of justice. Instead they function principally as lawyers for the government. The United States Supreme Court and the supreme courts of the several states have only limited oversight role over the state of civil justice and the regulation of lawyers. They do not have the extensive supervisory responsibilities characteristic of a supreme court with an administrative role such as that of the Supreme Court of Korea. They are composed principally of former lawyers. Not to be lost sight of is that in America judges are lawyers in judges' robes. See generally Benjamin H. Barton, The Lawyer-Judge Bias in the American Legal System (2010).

${ }^{8}$ See generally, James R. Maxeiner, Gyooho Lee \& Armin Weber, Failures of American Givil Justice in International Perspective (2011).
} 
the United States has rejected loser pays, for rejection assumes a conscious choice. Better it is to say that American courts do not practice it. ${ }^{9}$

Practices do not need justification. The American practice of no indemnity, Professor Leubsdorf has shown, developed without one. "One of the most curious features of the American rule in the nineteenth century," he writes, "was its almost total absence of justification." 10 Today's justifications post-date the practices. They are practically apologies. The practices persist, because they suit the needs of lawyers, and because no one has legislated otherwise. Lawyers work in their world and in their world, it is "natural" to obtain their fees from their clients. ${ }^{11}$ They would have to move out of that world to create a system of fee shifting. Of course, that lawyers remain in their world does not make them evil, it only makes them ordinary.

Despite witticisms to the contrary, lawyers are people. Historically they were, and today by-and-large still are, independent small businessmen. Like small businessmen everywhere who are dependent on their businesses for existence, they share two concerns: (1) that they have sufficient customers; and (2) that those customers pay promptly and well. There is nothing cynical in this observation: altruism has its limits where personal existence is at stake. Who would not steal bread if the alternative is to starve ${ }^{12}$

The American practice of no indemnity responds to the first concern of lawyers as businessmen: getting customers. It helps them bring clients in. For lawyers' clients it cuts the risks of suing nearly in half. If they lose, they need pay only their own lawyers and not lawyers for opposing parties. For lawyers, it is easier to collect fees from their clients or from judgments subject to contingent fees, than to extract them from unwilling and possibly insolvent vanquished parties. Should they lose, they need not explain to clients the obligation to pay yet another lawyer's fee. ${ }^{13}$

Unregulated fee agreements let lawyers control their financial destinies. Lawyers take charge not only of the credit risks inherent in the choice of clients, but of the terms of those risks, namely reliability, timing and

\footnotetext{
${ }^{9}$ Cf. Acrambel v. Wiseman, 3 U.S. (Dall.) 306 (1796) ("The general practice of the United States is in opposition to [allowing attorneys' fees]; and even if that practice were not strictly correct in principle, it is entitled to the respect of the court, till it is changed, or modified, by statute.").

${ }^{10}$ Leubsdorf, supra note 3 , at 28.

$11 \mathrm{Id}$.

12 Salaried employees are no different than independent businessmen; only their concerns differ due to their different circumstances. They eare (1) whether their employer is healthy, and (2) whether they continue to have a position with their employer. So too is it for politicians. They care (1) whether their government stays in power, and (2) whether they remain a part of that government. Lest we forget, it is true of law professors, too. Their concerns are those of salaried employees.
}

${ }^{13}$ Leubsdorf, supra note 3 , at 17 . 
level of payment. They are not subject to outside constraints such as court decisions on costs or willingness or ability of vanquished parties to pay. At the outset of litigation lawyers can secure their investments through arrangements with their clients.

That the bar finds these practices congenial is suggested by their absence from the Federal Rules of Civil Procedure of 1938 and in the discussions that led up to the rules. ${ }^{14}$ The organized bar's silence both before and since 1938 has been unbroken. None of the three principal national law reform organizations, the American Law Institute, the Uniform Laws Commission, and the American Judicature Society, seems ever to have substantially addressed the practice of no indemnity. Such proposals as there have been, have come from law reformers external to the bar.

In the Federal Rules of 1938, the bar achieved a long-sought goal: transfer of responsibility for civil procedure from legislators to judges. That meant, in practical effect, transfer to lawyers. Yet the rules have little to say about costs or attorneys' fees and nothing to say about fee regulation or feeshifting. If the bar had been dissatisfied with those practices, they would have found place in the discussions. The bar did care in 1848 when New York adopted the other icon of American civil procedure history, the New York Code of Givil Procedure of 1848.

The New York Code of Civil Procedure of 1848 addressed both fee regulation and fee shifting directly. The Code repealed all fee regulations, but it retained fee shifting. The bar had long sought the former, while according to Field, everyone then still believed in the latter. The drafters of the 1848 Code, led by Field, justified abolition of fee regulation as necessary to protect freedom of contract between private parties. They rejected the idea that lawyers are public officers, chosen to do public duties, and that therefore their fees could be regulated. ${ }^{15}$ The drafters justified retention of fee-shifting in the interest of justice. But compared to a proposal that Field alone had made earlier in the decade, the fee-shifting provisions of

\footnotetext{
${ }^{14}$ Neither issue seems to have come up substantively in the course of the drafting of the 1938 rules. There was a suggestion that they should: Philip M. Payne, Costs in Common Law Actions in the Federal Courts, 21 VA. L. REV. 397, 430 (1934). I do not know of any instance where these practices have come seriously under discussion in the establishment law reform organizations. Serious proposals have come from outside the bar. See, e.g., Marie Gryphon, Manhattan institute for Policy Research, Greater Justice, Lower Cost: How a "Loser pays" Rule would improve the American Legal System, Givil Justice Report No. 11 (December 2008).

15 First Report of the Commissioners on Practice and Pleading, Code of Procedure 205 (1848). Accord, Field, Letter, supra note 4, at 55. In rejecting the characterization as officers of the court, Field may have been provocative, but not off the mark for the United States. See Eugene R. Gaetke, Lawyers as Officers of the Court, 42 VAnderbilt L. Rev. 39 (1989) ("the characterization [is] vacuous and unduly self-laudatory. It confuses lawyers and misleads the public.”).
} 
the 1848 Code were substantially watered down, both as proposed by the three-member drafting committee, and still more so, as adopted by the legislature. ${ }^{16}$ Leubsdorf senses a compromise, but how and by whom, remains unknown. ${ }^{17}$ The fee-shifting provision was soon criticized as having "obviously failed" to achieve its objective. ${ }^{18}$ Although the subsequent history remains to be written, it is one of neglect of fee-shifting.

\subsubsection{Pernicious Products of American Practices}

Lawyer control of litigation magnifies the effect of the no indemnity practice and extends its impact beyond reduction in value of valid claims. It destroys meritorious claims and promotes baseless ones. Through control of litigation, lawyers can force opposing parties to devote resources to litigation; thanks to the no indemnity practice, those resources are forever lost. In most cases the only substantial external check on lawyers' wreaking such havoc is the possibility that opposing parties retaliate.

At every step, parties must consider process costs. Even where there is no deliberate intention to create expenses, it has long been true that "unless the case involves a large amount of money [the] lawyer's bill eats up [the] judgment if obtained."19 Every lawyer knows that in most cases, the other side, if so inclined, has the ability to render a victory Pyrrhic. A party

\footnotetext{
${ }^{16}$ Field's 1842 proposal had mandatory fee-shifting as fixed percentages of judgment amounts. The Commission's 1848 draft code made fee-shifting discretionary using "may" instead of "shall" and left percentage amounts blank for the legislature to fill in. The law as adopted by the legislature made the court's discretion explicit and limited its exercise to "difficult or extraordinary cases." Field's 1842 proposal is: Field, Letter, supra note 4. The Commission's 1848 Report on costs is FIRST REPORT, supra note 15, at 204-12 (1848). The law adopted is: An Act to Simplify and Abridge the Practice, Pleadings and Proceedings of the Courts of this State, ch. 379, 1848 N.Y. LAws 544, § 258. [Bibliographic notes: 1842 Letter: The letter was sometimes distributed separately from the whole committee report and the volumes of documents. The committee report with the Appendix is collected in the documents series and is as of this writing available as a Google book. 1848 First Report: some electronic and print-on-demand editions to the First Report of the Commissions on Practice and Pleading are based on a hard copy in the New York Public Library where a contemporary user had pasted over the original sections relevant here $\$ \$ 262-263$ the text of the law as adopted.]

17 Leubsdorf, supra note 3 , at 20.

18 Henry Whitaker, Practice and Pleading under the Codes, Original and Amended with an Appendix of Forms 600 (1852).

${ }^{19}$ D.C., Letter to the Editor, The Constitutional Convention, the Judiciary and the Bar, New York Times, June 5, 1867. The General Report is misleading in suggesting that the American system does not ever eat up more than 50\% of the amount in controversy, if that amount exceeds $\$ 100,000$. I personally was involved in a second stage case over costs of $\$ 10,000$ where the amount of attorneys' fees in the second stage for the $\$ 10,000$ costs exceeded $\$ 100,000$ !
} 
prepared to spend money may not be able to buy a victory, but it can deny the opposing party one. ${ }^{20}$ Parties, of course, do not always engage their weapons of mass destruction. The practice is reminiscent of the Mutual Assured Destruction doctrine ("MAD") of Cold War days, where neither side attacked the other, because of fear of final retaliation. That reticence to use the weapon clouds the view of outside observers of a reality that is all too well-known to insiders.

The public seems resigned to destruction of meritorious claims; it may assume that litigation costs are inevitable. The public takes greater notice, however, of baseless claims that are enabled by no indemnity and lawyer control. $^{21}$ This combination permits weak parties with weak claims to extract settlements even from strong parties with strong defenses. ${ }^{22}$ It enables strong parties with weak claims to bully weaker parties with strong defenses into surrendering their claims entirely. ${ }^{23}$ While scholars may argue over the extent of the resulting distortions, about the totality of effect, or whether there are countervailing benefits, no one who has spent even a short time in litigation practice will reasonably deny that these distortions are routine features of American civil justice.

\subsection{Exceptions and Variations: The Common Denominator}

The General Report notes exceptions and variations to the American practice of no indemnity. No common theory supports them. ${ }^{24}$ There is, however, one common denominator: helping lawyers get well-paying clients. Three variations - contingent fee, one-way fee shifting, and class action litigation - help lawyers gain clients who otherwise would be unable to

\footnotetext{
${ }^{20}$ Cf., id. ("A man is painted naked, with a large bundle of papers under his arm, and saying, 'I, who won the suit, am now stripped to the skin; what then, must be the fate of him who lost it?' It is unnecessary to enlarge upon this evil; it has been felt too keenly by everyone engaged in legal proceedings to be forgotten.").

21 A notorious example is Pearson v. Chung, 961 A.2d 1067 (D.C. Ct. App. 2008) (lawsuit against dry cleaner claiming $\$ 67$ million in damages for a lost pair of pants). A new documentary film, Hot Coffee, challenges the assertion that another notorious case, Liebeck v. McDonald's Restaurants, P.T.S., Inc., No. D-202 CV-93-02419, 1995 WL 360309 (Bernalillo County, N.M. Dist. Ct. August 18, 1994), is a baseless case taking advantage of the system. See http://hotcoffeethemovie.com/.

22 According to the General Report, it is "the implicit encouragement of weak lawsuits (often with the sole goal to force the defendant to settle) - that sets the rule in the United States apart from pretty much the rest of the world." [1.2.3.3]

23 In 2010 Congress directed the Patent and Trademark Office to study the issue of trademark bullying. The Trademark Technical and Conforming Amendment Act of 2010, Pub. L. No. 111-146, 124 Stat. 66 (2010).

${ }^{24}$ Leubsdorf sees "a bizarre variety of opinions, which might go far to justify the view that policy analysis is totally arbitrary and manipulable." Leubsdorf, supra note 3, at 28.
} 
afford their services. Two variations - pro se representation and legal aid help lawyers divert pressures to take on undesirable clients, i.e., free riders who would not pay well or at all. Finally, the exception to fee shifting indemnity for costs - has been neutralized as a factor that might discourage clients by making costs trivial in most cases. We start with the exception of costs (26.2.1); we then proceed to variations that encourage desirable clients, i.e., business development (26.2.2); and we conclude with variations that help lawyers divert undesirable business to other providers, i.e., avoiding free riders (26.2.3).

\subsubsection{Costs: Loser Pays (in Theory), as Elsewhere}

For court costs, the rule (not a mere practice) in the United States is the same as elsewhere: loser-pays. The rule dates from the colonial era when lawyers were few and were not self-regulated. Costs discourage customers. While costs have never been abolished, lawyers have kept them low. ${ }^{25}$

Unlike in many countries, court costs in the United States are set without regard to amounts in dispute. For example, filing a lawsuit in federal court seeking $\$ 100,000$ in damages requires that plaintiff pay $\$ 350 .{ }^{26}$ In Germany, for a case of comparable magnitude, $€ 75,000$, plaintiff must pay $€ 1,968$ (or around $\$ 2,500$ ) in costs. ${ }^{27}$ Increase the claim ten-fold and the filing fee in Germany rises to $€ 11,118$ (around $\$ 15,000$ ); in the United States, the filing fee is still $\$ 350$. Moreover, thanks to inflation, sometimes what once were significant costs, now are trivial. ${ }^{28}$ Although court costs are low, sometimes additional costs ancillary to the case, for example for court-appointed experts (rarely used) can be high.

Application after trial of the loser-pays costs rule is unusual because there are so few trials. More commonly it appears only after a pre-trial motion. Only about $2 \%$ of cases go to trial. Unlike elsewhere, the trial judge does not automatically calculate costs and include them in the judgment. Instead the winning party must apply for costs and complete itemized requests. Since total costs are low, often application is too burdensome to bother with. Other times, it is easier just to include a rough estimate in the discount usually given for prompt, voluntary payment of a judgment.

The original justification for shifting costs was the same as for attorneys' fees: it is just that parties in the right be made whole. Attorneys'

\footnotetext{
25 See Leubsdorf, supra note 3 , at 14 .

2628 U.S.C. \$ $1914($ a).

$27 \mathrm{http} / / / \mathrm{www} \cdot$ prozesskostenrechner.de/.

${ }^{28}$ For example, in 1853 the federal courts introduced a case fee of $\$ 20$. It was originally intended as the attorney's fee. The federal courts still have the same case fee and it is still \$20. See Leubsdorf, supra note 3, at 21-22.
} 
fees were considered costs. Today, insofar as costs are discussed, the justification given for cost-shifting may just as well be the policy ground of discouraging litigation. When they are held low, on the other hand, the justification given likewise will be a policy one, but this time, to encourage litigation.

\subsubsection{Business Development}

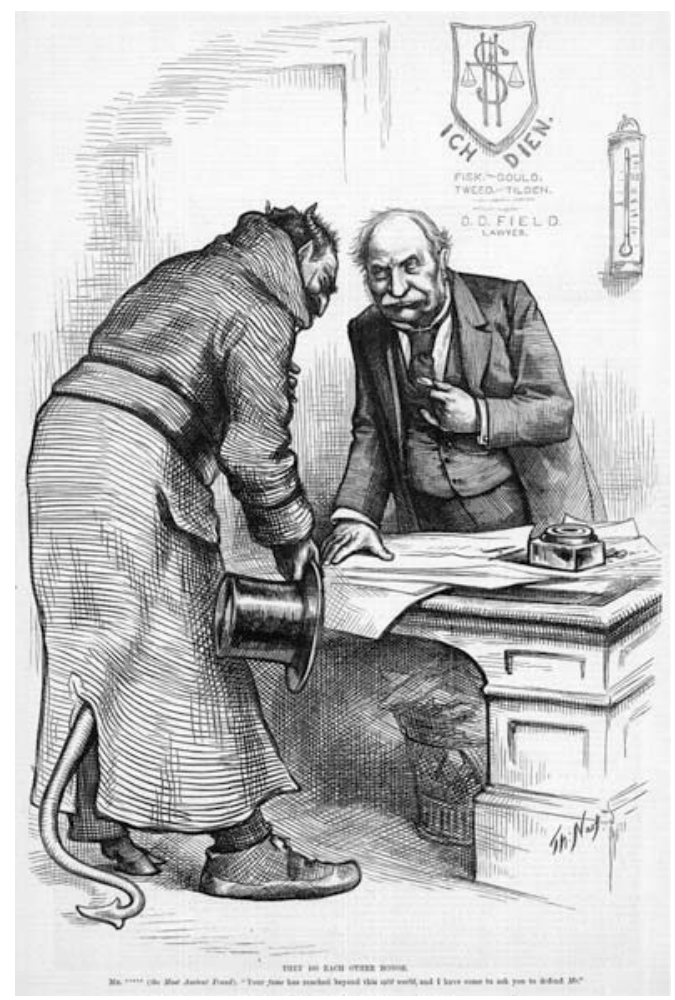

They Do Each Other Honor

Mr. (the Most Ancient Fraud). "Your fame has reached beyond this cold world, and I have come to ask you to defend Me."

Thomas Nast, HARPer's WeekLy Magazine, 152 (Feb. 24, 1877) 29

The American practice of no indemnity is not a complete solution to overcoming customer reluctance to buy into lawsuits. American lawsuits are expensive. The General Report finds that fact gathering in the United States is more expensive than anywhere else in the world. It reports:

\footnotetext{
${ }^{29}$ See Alexander Tabarrok, Two Cheers for Contingent Fees (2006) (book description: "If America is a lawsuit hell, then contingent-fee lawyers are often considered its devils.").
} 
The practical impact of not shifting the lion's share of evidence costs (including expert witness fees) is tremendous: it entails a huge burden for the victor as well as a huge relief for the vanquished. In fact, not shifting the bulk of evidence costs is perhaps the defining feature that separates the United States from all other jurisdictions covered here.

Ordinary people cannot afford the huge burden. ${ }^{30}$ At the outset of the lawsuit, they have to advance their lawyers a substantial part of the attorneys' fee. At the conclusion of the lawsuit, they have to turn over a substantial part of the award to their attorneys.

Once lawyers were freed to agree with their clients on fees, they could design contractual and other solutions to lift the burden from ordinary people and turn them into well-paying clients. The door was open to innovative arrangements designed by lawyers to turn ordinary people into paying customers. First came contingent fees designed for people with large openended claims. Then came one-way fee-shifting for ordinary people with claims newly created by statute. Then last came class actions for ordinary people with mundane claims too small to be handled alone profitably.

\subsubsection{Contingent Fees}

The General Report observes that contingent fee agreements are widely considered "a hallmark of the US-American legal system." The essence of a contingent fee agreement is that the lawyer's fee is due if, and only if, the lawyer achieves a favorable result. The fee is usually a percentage of the amount recovered. Typically that amount is 33\%. ${ }^{31}$ The contingent fee agreement may provide that the lawyer advances court costs and other expenses to the client to be paid or not paid later as the parties agree.

Ordinary people benefit at both key points of the lawsuit. At the outset, they do not have to advance fees that they do not have. At the conclusion, they do not have to pay at all if they lose; if they win, they do not have to pay more than they recover. The huge burden and risk are taken on by the lawyer. The downside for the client is that the lawyer's share is high, especially in those cases that do not incur the high costs of litigation.

Lawyers benefit from contingent fee arrangements by gaining clients that they would not otherwise have. They are compensated for taking on the process risk by being given a share of the recovery. In well-chosen cases, that recovery may vastly exceed the investment in services provided. They are able more surely and easily to collect their fees from judgments than from winning or losing parties.

\footnotetext{
${ }^{30}$ See Leubsdorf, supra note 3 , at 31 .

31 Jeffrey D. Swett, Determining a Reasonable Percentage in Establishing a Contingency Fee: A New Tool to Remedy and Old Problem, 77 Tenn. L. Rev. 653, 655 (2010); see generally, Herbert M. Kritzer, Risks, Reputations, AND REWARDS: CONTINGENGY Fee Legal Practice in the United States 9-10 (2004).
} 
Contingent fees became widely used in the second half of the nineteenth century after lawyers were freed to agree with their clients on fees. The practice of contingent fees was and is controversial, because it gives lawyers financial interests in their cases. ${ }^{32}$ It is distasteful because it makes civil justice - which is about determining rights to resolve controversies - into cost/benefit risk decisions. ${ }^{33}$ It is troubling because in large cases it can lead to enormous fees out of all proportion to time or risk invested - fees of $\$ 40$ million have been reported. ${ }^{34}$ Dissatisfaction with contingent fees has engendered spotty regulation with haphazard enforcement. ${ }^{35}$

The justification given for contingent fees is that they provide ordinary people with access to civil justice. Contingent fees, however, can only be a partial solution to access to justice. Contingent fees help only some clients. These are usually clients who as plaintiffs seek monetary relief and have large and open-ended claims. ${ }^{36}$ Claims for fixed sums are less-desired, since they make transparent the costs of the contingent fee arrangement. Claims that are open-ended make the arrangement into a sharing of good fortune. This explains why tort claims are nearly all contingent fee based, but contract claims are not.

Contingent fees do not facilitate representation when claims are too small to generate sufficient revenues. Innovative Americans lawyers found solutions that helped them make representation in these cases possible and profitable as well. We turn now, first to one-way fee shifting statutes (Section 26.2.2.2 below), and then to aggregate or class action litigation (Section 26.2.2.3 below).

\subsubsection{Only in America: One-Way Fee-Shifting ${ }^{37}$}

What are lawyers to do with cases that do not lead to monetary recoveries or only to small ones insufficient to support their fees? One way would be to

\footnotetext{
32 Compare Edwin Countryman, The Ethics of Compensation for Professional Services: An Address before the Albany Law School and an Answer to Hostile Critiques (1882) with Lester Brickman, Lawyer Barons: What Their Contingency Fees Really Cost America (2011). See generally, Peter Karsten, Enabling the Poor to Have Their Day in Court: The Sanctioning of Contingency Fee Contracts, A History to 1940, 47 DePAul L. REv. 231 (1997). Acceptance of contingent fees presupposes loosening or ending historic limitations on lawyers having financial interest in their cases.

33 John A. Day, Should you risk taking the case?, TRIAL, January 2008, at 20.

${ }^{34}$ See, e.g., Lawrence v. Miller, 48 A.D.3d 1, 853 N.Y.S.2d 1(2007) (upholding a $\$ 40$ million dollar, $40 \%$ contingency fee, which in the view of the dissent amounted to a nearly $100 \%$ fee).

35 See Swett, supra note 31, 659 et seq.

${ }^{36}$ See Maxeiner, supra note 3, at 207-209.

37 It's not quite only in America; the General Report notes that there is also one-way fee-shifting in Japan in personal injury cases. [1.2.2.1]
} 
abandon the American practice of no indemnity and adopt the global norm of loser-pays. That would, however, drive away customers who are unable to accept the risks posed by a loser pays rule.

The American legal system offers an ingenious solution: one-way fee shifting. If lawyers win for their clients, opposing parties pay their legal fees. On the other hand, if they lose for their clients, although they are not paid at all, at least their clients do not have to pay the attorneys' fees of the opposing parties. Used first in the last third of the nineteenth century to facilitate private enforcement of trade regulations, ${ }^{38}$ the idea has been a hit. Hundreds of statutes direct that losing defendants pay fees of winning plaintiffs' lawyers, while leaving winning defendants to pay their own lawyers' fees. ${ }^{39}$ One way fee-shifting remains concentrated in private enforcement of public law norms and does not extend to the historic private law.

One-way shifting is said to enlist private parties to act as "private attorneys general" in the enforcement of public law norms. ${ }^{40}$ In a nation that is devoted to equality of treatment, in a profession that promotes fair contests, the challenges that such a "heads I win, tails you lose" rule poses to fairness are obvious. The challenges are not denied, but are confessed and avoided on instrumental grounds. Critics question the accuracy and the justice of the instrumental justification.

\subsubsection{Class Actions: Where's the Agreement?}

Most cases are not eligible for one-way fee-shifting. Many claims remain too small individually to support the high expenses of American litigation. American lawyers have an answer for that, too: aǵgregate or class-action litigation. Here a lawyer represents tens, hundreds or even thousands of parties with claims. Sometimes claims are large, but litigation expenses too high to handle them one-at-a-time. Sometimes claims are small, some as small as a few dollars each. In a legal system that prizes case-by-case consideration of each individual case, class action litigation seems strangely out-of-place. For a fee system of unregulated fee agreements, a valid agreement between one lawyer and a hundred or a thousand clients, each with a claim of few dollars, is hard to find. Since 2003, the Federal Rules of Civil Procedure have required that courts, as part of their approval of class action settlements, decide on the "reasonable attorneys' fee" to be allowed. ${ }^{41}$

\footnotetext{
38 See Leubsdorf, supra note 3 , at 25.

${ }^{39}$ See Harold J. Krent, Explaining One-Way Fee Shifting, 79 VA. L. REv. 2039, 2051 n.48 (1993) (citing examples).

40 Alyeska Pipeline Service Co. v. The Wilderness Society, 421 U.S. 240, 261-263 (1975).

${ }^{41}$ Rule 23(h). See generally Jonathan R. Macey \& Geoffrey P. Miller, Judicial Settlement of Class Actions, 1. J. Legal ANALYSis 167 (2009).
} 


\subsubsection{Diversion of Undesirable Business}

\subsubsection{Self-Representation (Pro Se)}

Self-representation (pro se) has been possible in the federal courts for as long as they have been in existence. Federal law, first adopted in $1789,{ }^{42}$ permits parties in federal court to "plead and conduct [their] own cases personally." 43 The reality is, of course, that few people can do that satisfactorily in any but the simplest of cases. This right is hardly meaningful except in courts where the unrepresented are helped to represent themselves. ${ }^{44}$ That is true in some small claims courts. When proposals are made to increase the upper level jurisdictional amounts in small claims courts, litigation lawyers often lead the opposition.

The possibility of pro se representation, however, is essential to maintaining the present system. If there were a rule of mandatory representation, the denial of justice to those who could not afford counsel would be obvious and irrefutable. The American legal system would be compelled to offer legal aid as of right. That happened in Germany. There, where lawyers did not and do not regulate themselves, they were required to provide counsel for free for those who could not afford lawyers. ${ }^{45}$

\subsubsection{Legal Aid}

To represent oneself in court where the opposing side is represented by a lawyer takes special qualities which few people have. What are people who lack those qualities to do when they have litigation that does not qualify for contingent fee representation or one-way fee-shifting? Those claims account for the vast majority of legal claims. They include most defense cases, most cases for non-monetary relief, and most cases for amounts below $\$ 100,000$. In the United States, people with such claims must beg for help. Unlike other legal systems, they have no claim of right to litigation

\footnotetext{
42 \& 35 of the Judiciary Act of 1789.

4328 U.S.C. \$1654.

${ }^{4}$ See generally The Future of Self-Represented Litigation: Report from the March 2005 Summit (National Center for State Courts, 2005), available at www.nese. org; Tiffany Buxton, Foreign Solutions to the U.S. Pro Se Phenomenon, 34 CaSE W. ReS. J. InT'L L. 103 (2002); Drew Swank, Note and Comment: The Pro Se Phenomenon, 19 BYU J. Pub. L. 373 (2005); Nina Ingwer Van Wormer, Note: Help at Your Fingertips: A Twenty-First Century Response to the Pro Se Phenomenon, 60 VAND. L. REv. 983 (2007).

45 See Heinrich Dittenberger, Fünfzig Jahre Deutscher Anwaltverein 1871/1921, aus JW 1921, reprinted in 125 Jahre Deutscher Anwaltverein: Ein Überblick (Deutscher Anwaltverein, ca. 1996); James R. Maxeiner, A Right to Legal Aid: The ABA Model Access Act in International Perspective (March 17, 2011) available at SSRN: http://ssrn.com/abstract=1791209.
} 
help. ${ }^{46}$ Many forego their legal rights simply because they cannot afford to pay for them.

Legal aid, or rather the lack of legal aid, in the United States, demonstrates the lawyer domination of the American system of costs and fees. Who can blame the lawyers? Bluntly put, why should small businessmen want customers who cannot pay for their products? Who in modern economies provides their goods or services to others for free?

At the beginning of the nineteenth century, in both the United States and Germany, lawyers represented the very poor without charge (in the United States, in forma pauperis). In the United States, lawyers and judges ran the system; they resisted requiring colleagues to work for free. When demand for representation grew, the bar ignored it; private parties outside the legal system had to provide the poor with legal services. In Germany, government officials ran the system; they drafted lawyers to provide free representation as their price for granting permission to practice. When demand for representation grew, the bar pleaded for relief; the government provided that it would pay for their work. ${ }^{47}$

\subsection{The Shakespearean Question: Answers by Field, Nast, and Shakespeare, and Another Question}

The General Report begins its first substantive section with what it calls a "Shakespearean Question": "To shift or not to shift." [1.2.1] It ends the report with a provocative answer: "one can perhaps say that at least among the common law jurisdictions, the United States has got it right after all: if lawyer fees are unregulated, unpredictable, and high, shifting them to the loser is so fraught with problems that it is better not to undertake it at all." [1.5.2] The answer assumes that fees are unregulated, unpredictable, and high. They are, but they should not be.

The United States does not have it right. No indemnity, unregulated fee agreements, and lawyer control of litigation, combine in a deadly cocktail that poisons civil justice in America. Civil justice fails in its stated goal of "just, speedy and inexpensive determination of every action and proceeding." ${ }^{8}$ It is not a reliable instrument for applying law to facts to resolve disputes justly. Process considerations and party resources - rather than law and justice - determine too many cases.

David Dudley Field, Jr. knew that. In 1842 he made the case for fee shifting:

\footnotetext{
46 Lassiter v. Dept. of Social Services, 452 U.S. 18 (1981).

47 See James R. Maxeiner, A Right to Legal Aid, supra note 45.

${ }^{48}$ FED. R. Giv. P. 1. See generally, MAXEINER ET AL., supra note 8.
} 
The losing party ought to indemnify the other as far as possible against his losses by the suit. The former is in the wrong, the other is in the right; one ought not to lose by the wrong of another. All men we believe have equal rights. Their abilities to carry on lawsuits out of their own property are unequal. Unless then he who is in the wrong is made to pay the full amount of his adversary's expenses, just in that proportion has the rich man an advantage over the poor one, and the rights of the poor are unequally unprotected. If you would discourage unjust litigation, you must make the unjust litigant indemnify his adversary. ${ }^{49}$

Nast too understood the pernicious products of allowing one side to gain the upper hand through money. He reminded Field of that through an answer he found in Shakespeare:

Plate sin with gold and the strong lance of justice hurtlessly breaks:

Arm it in rags, a pigmy's straw doth pierce it.

King Lear, act IV, scene 6

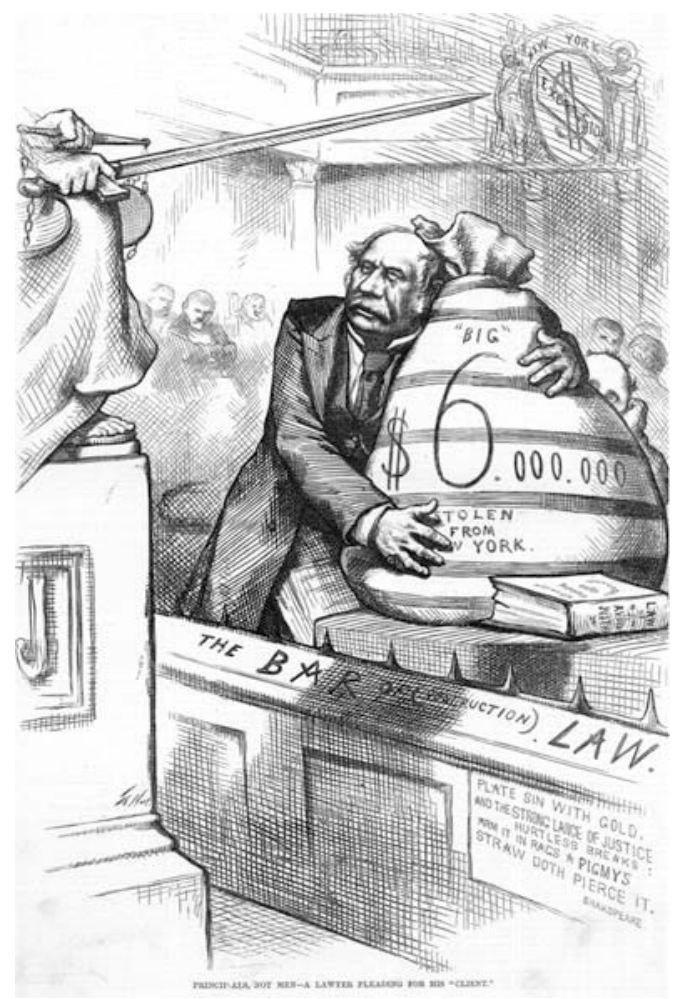

Principals not Men - A Lawyer Pleading for his "Client"

"The Bar of (Obstruction). Law."

Thomas Nast, Harper's Weekly MagaZine, August 7, 1875

${ }^{49}$ Letter, supra note 4 , at 56. 


\subsection{Conclusion}

The American experience is a lesson and a warning to other jurisdictions that may be considering the American model of no fee shifting and unregulated fee agreements.

The ultimate question that needs to be answered is not, "to shift or not to shift." It is, how can fee shifting and fee regulation be reconciled?

Deregulating fees, so notes the General Report, is intimately related to shifting them. Some regulation of attorneys' fees recoverable is essential to loser pays. Otherwise, richer parties could win by outspending poorer opponents and could compound the injustices of their victories by imposing their attorneys' fees as costs on the vanquished poor. Thus in New York in 1840, Theodore Sedǵwick, Field's law office associate, in his loser-pays system, limited fees shifted to those fees for "a lawyer of respectability" and not those for a lawyer of "remarkable or extraordinary ability."50 Field's preferred approach was a percentage of the amount of the recovery. ${ }^{51}$

If fees are shifted, however, clients expect that fees will be fully shifted and that they will be fully compensated when they win. The Virginia legislature saw that already in a statute of 1778: "it is, unreasonable that the party who prevails ... should be subject to the payment of a greater fee to his lawyer than he can recover from the adverse party."52 That is a direct challenge to a lawyer of greater ability or, to a lawyer for a client with greater means to pay. In the United State the bar regulates itself and the lawyers that lead the bar are lawyers of greater ability who work for clients of greater means. Small wonder that they championed a market approach to fees while allowing fee shifting to disappear.

Although the American experience is a warning to the world, the dangers elsewhere are not great as in the United States, since legal fees elsewhere are not as unpredictable and usually also not as substantial. American fees are so substantial only partly because American lawyers are self-regulated. More important still is that American lawyers, through their control of litigation, determine what fees will be. So long as they drive the legal system, fees are likely to remain high.

\footnotetext{
50 Theodore Sedgwick, How Shall the Lawyers be Paid? Or Some Remarks Upon Two Acts Recently Passed on the Subject of the Costs of Legal Proceedings in A LetTer to John Anthon (1840).

51 Field, Letter, supra note 4, at 57.

521778 Va. Acts, ch. 14, § 5, in A collection of all such public acts ... as are now in force 84 (Richmond 1785), reprinted in The First Laws of the State of Virginia 84 (J. Cushing comp. 1982), as cited in Leubsdorf, supra note 3, at 11.
} 